\title{
Nowe typy tzw. przestępstw fakturowych w Kodeksie karnym - powrót do szczególnej prawnokarnej ochrony „mienia społecznego”?
}

\begin{abstract}
The paper makes a distinction between criminal law protection of collective property and that of individual property. It discusses both the amendments of the Polish Criminal Code made on 10 February 2017 and arguments for their introduction. In conclusion, the paper points to some similarities between more severe criminal liability for crimes against collective property under the communist regime and stricter criminal liability for invoice frauds.
\end{abstract}

Keywords: criminal protection of collective property, counterfeiting, invoice

\section{Wprowadzenie}

Własność, jako najszersze z praw rzeczowych, pozostaje w kręgu zainteresowania prawa karnego od wykształcenia w grupach pierwotnych podstawowego podziału dóbr, w tym przedmiotów indywidualnej własności ${ }^{1}$. Choć zasadnicza treść prawa własności zdaje się niezmienna ${ }^{2}$, to w historii wprowadzano rozróżnienie różnych form własności ${ }^{3}$, co znaj-

${ }^{1}$ R. ZawŁocki: Rozdział I. Przestępstwa przeciwko mieniu. Zagadnienia ogólne. W: System prawa karnego. T. 9: Przestępstwa przeciwko mieniu i gospodarcze. Red. IDEM. Warszawa 2015, s. 8.

${ }^{2} \mathrm{Na}$ treść prawa własności składa się tzw. triada uprawnień, obejmująca posiadanie, korzystanie i rozporządzanie rzeczą; por. E. GNIEweK: Rozdziat V. Treść i wykonywanie prawa własności. W: System prawa prywatnego. Prawo rzeczowe. T. 3. Red. E. GNIEWEK. Warszawa 2013, s. 381.

${ }^{3}$ A. Stelmachowski i K. Zaradkiewicz wskazują, że w miejsce istniejącego w okresie PRL podziału własności na społeczną i indywidualną, obecnie zarysował się podział 
dowało odzwierciedlenie w jej prawnokarnej ochronie. Charakterystyczną odmiennością wynikającą z istniejącego w powojennej Polsce ustroju socjalistycznego było występowanie osobnej kategorii własności, określanej jako społeczna, na wzór znanej z prawodawstwa radzieckiego własności socjalistycznej. Kategoria ta stanowiła dobro prawne chronione przez szereg przepisów prawa karnego.

Odróżnić ją należy od pojęcia mienia społecznego, które wprost było wskazywane w treści przepisów, a które stanowiło oznaczenie przedmiotu czynności wykonawczej ${ }^{4}$. Pojęcie mienia społecznego, które zniknęło z prawnokarnej kodyfikacji wraz z wejściem w życie obowiązującego Kodeksu karnego z 1997 r., od strony przedmiotowej oznaczało socjalistyczne mienie ogólnonarodowe, mienie spółdzielcze lub mienie innej organizacji ludu pracującego, o czym przesądzała definicja zawarta w art. 120 § 6 Kodeksu karnego z 1969 r. ${ }^{5}$. Przed jego wejściem w życie pojęcie to było w sposób tożsamy dekodowane z obowiązujących ówcześnie norm konstytucyjnych ${ }^{6}$.

W skład pojęcia mienia społecznego bez wątpienia wchodził również majątek Skarbu Państwa, nazywany mieniem państwowym. Ten jednak, w zakresie interesów fiskalnych, był chroniony szczególnymi przepisami karnoskarbowymi. Niemniej po wprowadzeniu podatku od towarów i usług przedmiotem dociekań doktryny oraz orzecznictwa było zagadnienie, czy wyłudzenie ze Skarbu Państwa nienależnego zwrotu VAT może być kwalifikowane na gruncie prawa karnego powszechnego ${ }^{7}$. Możliwość ochrony interesów majątkowych Skarbu Państwa przed tego typu zamachami została rozstrzygnięta przez ustawodawcę dnia 1 marca 2017 r., kiedy to weszła w życie ustawa nowelizująca w głównej mierze Kodeks karny oraz kilka innych ustaw ${ }^{8}$. Zasadnicze kontrowersje z nią związane wynikały ze znacznego zaostrzenia ustawowego zagrożenia za czyny po-

na własność prywatną i własność państwową, tak: A. STelmachowsKi, K. ZaRAdKIEwicz: Rozdziat IV. Modele wtasności i ich uwarunkowania społeczno-ustrojowe. W: System prawa prywatnego..., s. 294.

${ }^{4}$ Tak też W. GuTENKUnST: Niektóre problemy kodyfikacji przestępstw przeciwko własności. PiP 1957, nr 10, s. 578; L. LeRnelL: Własność społeczna jako przedmiot ochrony prawa karnego: o przedmiocie przestępstwa zagarnięcia mienia społecznego. Warszawa 1959, s. 106; W. GuTENKUnst: Zagarnięcie mienia społecznego. Warszawa 1956, s. 15.

${ }^{5}$ Dalej jako: d.k.k.

${ }^{6}$ Por. L. Lernell: Nasze ustawodawstwo karne na straży własności społecznej i interesów mas pracujacych. NP 1953, nr 3, s. 11.

7 Por. K. RADzIKOwsKI: Nowelizacja kodeksu karnego i kodeksu karnego skarbowego $w$ zakresie tzw. przestępstw fakturowych. „Przegląd Podatkowy” 2017, nr 3, s. 38 i przywołana tam literatura oraz orzecznictwo.

${ }^{8}$ Ustawa z dnia 10 lutego 2017 r. o zmianie ustawy - Kodeks karny oraz niektórych innych ustaw, Dz.U. poz. 244. 
legające na wykorzystywaniu nieprawidłowo wystawionych faktur, które to działanie wykorzystywane było przez grupy przestępcze wyłudzające nienależny zwrot podatku VAT lub akcyzowego od Skarbu Państwa. Rozwiązaniu temu zarzucano naruszenie zasady proporcjonalności oraz naruszenie wewnętrznej spójności Kodeksu karnego9.

Nie może ulegać wątpliwości, że wprowadzenie powyższej nowelizacji stanowiło próbę zapobiegnięcia wielomilionowym stratom Skarbu Państwa ponoszonym w wyniku wyżej zakreślonych mechanizmów przestępczych. Przedmiotem niniejszego artykułu będzie zatem podjęcie próby udzielenia odpowiedzi na pytanie, czy wprowadzenie wskazaną nowelizacją nowych typizacji, w tym potocznie zwanych zbrodni fakturowych, stanowi przejaw powrotu do zróżnicowania prawnokarnej ochrony mienia ze względu na jego formę.

\section{Istota prawnokarnej ochrony mienia społecznego}

Ochrona mienia społecznego w powojennej Polsce ulegała przeobrażeniom na przestrzeni lat. Jej waga została podkreślona nawet w Konstytucji Polskiej Rzeczypospolitej Ludowej z dnia 22 lipca 1952 r., w której w art. 77 ust. 1 stwierdzono, że każdy obywatel PRL obowiązany jest strzec własności społecznej i umacniać ją jako niewzruszoną podstawę rozwoju państwa, źródło bogactwa i siły Ojczyzny. Obok przytoczonej normy konstytucyjnej jednoznacznie pozytywnie wartościującej własność społeczną prawodawca począł obejmować opisywany rodzaj własności w przyjmowanych aktach prawnych z zakresu prawa karnego ${ }^{10}$, chociaż aż do kodyfikacji karnej z 1969 r. przepisy Kodeksu karnego nie przewidywały odrębnych typizacji, których przedmiotem wykonawczym byłoby mienie społeczne. Ze względu na liczbę regulacji dotyczących omawianego zakre-

${ }^{9}$ Por. V. KonarsKa-WrzoseK: Przestępstwa fakturowe - ich waga, kwalifikacja prawna i miejsce $w$ systemie polskiego prawa karnego. IN 2017, nr 2, s. 89; M. UTRACKA: Przestępstwa fakturowe: czy sa przestępstwami przeciwko wiarygodności dokumentów?. CPKNP 2018, z. 3, s. 104.

${ }^{10}$ Jako przykłady aktów prawnych, które w początkowym okresie istnienia Polskiej Rzeczypospolitej Ludowej przewidywały zaostrzoną odpowiedzialność karną za przestępstwa godzące w mienie społeczne, można wymienić Dekret z dnia 13 czerwca 1946 r. o przestępstwach szczególnie niebezpiecznych w okresie odbudowy Państwa, Dz.U. nr 30, poz. 192 ze zm., który rozszerzył odpowiedzialność za nadużycia służbowe na pracowników przedsiębiorstwa państwowego lub aparatu spółdzielczego (art. 46) czy Dekret z dnia 16 listopada 1945 r. o postępowaniu doraźnym, t.j. Dz.U. 1949, nr 33, poz. 244 ze zm., który przewidywał stosowanie postępowania doraźnego, w ramach którego można było orzec nawet karę śmierci za przestępstwa kradzieży i przywłaszczenia mienia państwowego lub organizacji społecznej o znaczeniu ogólnopaństwowym (art. 1 ust. 1 pkt 2). 
su niemożliwe jest w tym miejscu szczegółowe opisanie ich wszystkich. Warte jednak jest odnotowania, że dla wzmocnienia ochrony mienia społecznego środkami prawa karnego wydawane były nawet szczególne akty prawne, jak dekret z dnia 4 marca 1953 r. o wzmożeniu ochrony własności społecznej ${ }^{11}$ czy ustawa z dnia 21 stycznia 1958 r. o wzmożeniu ochrony mienia społecznego przed szkodami wynikającymi z przestępstwa ${ }^{12}$.

Co istotne, bezpodstawne byłoby odróżnienie mienia społecznego bez wprowadzenia odrębności w prawnokarnej reakcji na ataki na poszczególne rodzaje mienia społecznego. Wzmożenie ochrony mienia społecznego przejawiało się zasadniczo w zwiększeniu zagrożenia karą przestępstw w nie godzących. Różnicę tę najlepiej ukazać na przykładzie Kodeksu karnego z 1969 r. w brzmieniu z jego wejścia w życie. Choć jako godzące w mienie społeczne można wskazać wiele typizacji ${ }^{13}$, trzeba zauważyć, że niektóre z nich przewidywały tożsamą karę za ich popełnienie niezależnie od rodzaju własności będącego przedmiotem zamachu ${ }^{14}$, z kolei inne jakkolwiek przewidywały surowe zagrożenie karą, tak chroniły również inne dobra prawne poza własnością społeczną ${ }^{15}$. Dlatego też różnice w zagrożeniu karą najlepiej ukazać na przestępstwach przeciwko mieniu, które w swym zestawie ustawowych znamion zawierały rozróżnienie rodzaju

11 Dz.U. nr 17, poz. 68 ze zm.

12 Dz.U. nr 4, poz. 11.

13 J. Klimek jako godzące lub mogące godzić w mienie społeczne podaje następujące typizacje: aferowe przestępstwo gospodarcze - art. $134 \$ 1$ d.k.k., zagarnięcie mienia społecznego znacznej wartości - art. 201 d.k.k., wyzyskanie działalności gospodarki uspołecznionej - art. 202 d.k.k., zwykłe zagarnięcie mienia społecznego - art. 199 d.k.k., wyrąb drzewa w lesie - $213 \$ 1$ d.k.k., zagarnięcie mienia oddanego pod zarząd lub ochronę art. 200 \$ 1 d.k.k., kradzież z włamaniem oraz kradzież szczególnie zuchwała - art. 208 d.k.k., rabunek mienia społecznego - art. 210 \$1 d.k.k., kradzież rozbójnicza - art. 209 d.k.k., wymuszane rozbójnicze - art. 211 d.k.k., paserstwo - art. 215 § 1 oraz art. 216 d.k.k., samowolne użycie pojazdu mechanicznego - art. $214 \S 1$ d.k.k., niszczenie urządzeń technicznych - art. 220 d.k.k., zniszczenie mienia społecznego - art. $212 \S 1$ d.k.k., wywołanie pożaru lub jego bezpośredniego niebezpieczeństwa - art. 138 § 1 d.k.k., niegospodarność art. $217 \S 1$ d.k.k., nadużycie funkcji publicznej - art. $246 \S 1$ d.k.k., dopuszczenie do powstania niedoboru - art. $218 \S 1$ d.k.k., sprzedaż towaru własnego w handlu uspołecznionym - art. $223 \S 1$ d.k.k., usługi na własny rachunek w uspołecznionym punkcie art. 223 § 2 d.k.k., oszustwo przy sprzedaży lub usługach - art. $225 \S 1$ d.k.k. Por. J. KLIMEK: Ochrona mienia społecznego w prawie karnym. Warszawa 1982, passim.

${ }^{14}$ Tak np. zabór pojazdu mechanicznego w celu krótkotrwałego użycia (art. 214 $\S 1$ d.k.k.) czy zniszczenie mienia (art. 212 § 1 d.k.k.).

15 Wskazać można tzw. wielką aferę gospodarczą stypizowaną w art. $134 \S 1$ d.k.k., w skład znamion której wchodził skutek w postaci poważnego zakłócenia w funkcjonowaniu gospodarki narodowej, przesądzający o tym, że wskazany czyn zabroniony groził również (a może głównie) w interesy gospodarcze państwa, na co zresztą wskazuje również jego umiejscowienie w rozdziale XIX d.k.k. zawierającym przestępstwa przeciwko podstawowym interesom politycznym i gospodarczym Polskiej Rzeczypospolitej Ludowej. 
mienia. Wskazać zatem należy, że zgodnie z art. 199 § 1 d.k.k. zagarnięcie mienia społecznego, tj. czyn polegający na przysporzeniu sobie lub komu innemu korzyści majątkowej przez kradzież, przywłaszczenie albo oszustwo lub inne wyłudzenie (art. $120 § 8$ d.k.k.), był zagrożony karą pozbawienia wolności od 6 miesięcy do lat 5. Jednocześnie zwykła kradzież była zagrożona karą tożsamą (art. $203 \S 1$ d.k.k.), jednak już przywłaszczenie innego mienia było zagrożone wyłącznie karą pozbawienia wolności do lat 3. Co więcej, ustawa przewidywała typ kwalifikowany polegający na zagarnięciu mienia społecznego znacznej wartości (art. 201 d.k.k.), który był zagrożony karą pozbawienia wolności na czas nie krótszy od lat 5 albo karą 25 lat pozbawienia wolności. W odniesieniu zaś do zwykłej kradzieży ustawa nie przewidywała analogicznego typu kwalifikowane$\mathrm{go}^{16}$. Skonstatować zatem można, że wzmożona ochrona własności społecznej polegała na zwiększeniu ustawowego zagrożenia w stosunku do części czynów zabronionych, których przedmiotem zamachu było tylko lub również mienie społeczne.

Zróżnicowanie środków w postaci zaostrzenia represji karnej zostało podbudowane znacznym dorobkiem nauki prawa karnego. Wśród autorów uzasadniających opisywane sposoby reakcji prawnokarnej z pewnością należy wskazać na L. Lernella, który w swoich pracach wielokrotnie podawał racje przemawiające za surowszym karaniem przestępstw godzących w mienie społeczne. Trzeba zaznaczyć, że jego wypowiedzi, jak innych jemu współczesnych autorów, bezspornie opierały się na założeniach ówczesnego systemu politycznego. Dość wskazać, że L. Lernell nazywał ochronę własności społecznej jednym z istotnych zadań budownictwa socjalistycznego ${ }^{17}$, co wynikało „, $\mathrm{z}$ ogromnego, decydującego znaczenia własności socjalistycznej dla przyspieszenia rozwoju sił wytwórczych kraju, dla rozkwitu gospodarki narodowej, dla bezustannego wzrostu dobrobytu i kultury mas pracujących"18. Autor ten wskazywał również, że „olbrzymie znaczenie własności społecznej polega na tym, że stwarza ona ogromne, niewyczerpane możliwości dla ciągłego rozwoju sił wytwórczych”"19 oraz że „celem ochrony własności społecznej jest

16 Różnica ta została usunięta Ustawą z dnia 23 lutego 1990 r. o zmianie Kodeksu karnego i niektórych innych ustaw, Dz.U. nr 14, poz. 84, która dodała art. $203 \S 2^{1}$ zawierający typ kwalifikowany kradzieży zwykłej zawierający takie samo zagrożenie karą od roku do 10 lat.

${ }^{17} \mathrm{~W}$ innej publikacji L. Lernell pisał, że własność socjalistyczna jest fundamentem ustroju socjalistycznego i dlatego jest chroniona jako podstawa ustrojowa państwa, a nie jego interes majątkowy; L. LERNELL: Ochrona mienia publicznego i osobistego $w$ radzieckim prawie karnym. PiP 1947, nr 11, s. 109.

18 L. LERNELL: Ochrona własności społecznej w prawie karnym. T. I: Nauka marksizmuleninizmu o ochronie własności socjalistycznej. Warszawa 1954, s. 3.

19 Ibidem, s. 18. 
wzrastający dobrobyt materialny i kulturalny całego społeczeństwa"20. Szczególną uwagę zwrócić jednak należy na fakt, że podkreślaną racją przemawiającą za wprowadzaniem przepisów z surowszą reakcją karną za opisywane rodzaje czynów było docelowo lepsze zaspokajanie potrzeb społeczeństwa czy też, według ówczesnej terminologii, „coraz szersza ochrona interesów człowieka pracy" 21 . Co więcej, walka z tymi czynami wpisywała się w założenie dążenia do zapewnienia maksymalnego zaspokojenia stale rosnacych materialnych i kulturalnych potrzeb całego społeczeństwa $\mathrm{w}$ drodze nieprzerwanego wzrostu i doskonalenia produkcji socjalistycznej na bazie najwyższej techniki ${ }^{22}$, co L. Lernell nazwał podstawowym prawem socjalizmu. Do argumentów wynikających z założeń ustroju socjalistycznego odwoływali się również inni autorzy ${ }^{23}$ oraz sam prawodawca w preambule do Dekretu z dnia 4 marca 1953 r. o wzmożeniu ochrony własności społecznejej.

Osobną grupę racji za ostrzejszą represją w stosunku do czynów godzących we własność społeczną było wskazywanie na społeczną szkodliwość (niebezpieczeństwo) tych czynów ${ }^{25}$. Jak pisała O. Górniok, zamachy tego rodzaju zaliczane były do grupy wielce niebezpiecznych ${ }^{26}$. Również J. Klimek podnosił, że odpowiednio zaostrzone kary z dekretów z 1953 r. stanowiły uwypuklenie społecznego niebezpieczeństwa czynów godzących w mienie społeczne ${ }^{27}$. Z kolei W. Gutenkunst podjął próbę określenia w sposób szczegółowy racji przemawiających za uznaniem takich czynów

20 Ibidem, s. 28.

21 Ibidem, s. 31, por. również L. LeRnelL: Nasze..., s. 27.

22 Ibidem, s. 28.

${ }^{23}$ Jak W. Gutenkunst, który wskazywał, że „własność społeczna jest podstawą państwa oraz źródłem bogactwa i siły PRL. Stanowi ona gwarancję rozwoju nowych, socjalistycznych form gospodarki i dlatego władza ludowa od początku swego istnienia prowadzi walkę z wszelkimi zamachami na własność społeczną. W walce tej obok środków wychowawczo-wyjaśniających olbrzymie znaczenie miała zawsze i ma nadal ochrona prawnokarna, której formy kształtowały się w zależności od rozwoju własności społecznej” (W. GutenKunst: Zagarnięcie..., s. 5) czy O. Górniok podnosząca, że „ochrona własności społecznej [...] to jedno ze szczególnie ważkich zadań spoczywających na ustawodawcy państwa socjalistycznego" (O. GóRNIOK: Zagarnięcie mienia społecznego. Warszawa 1976, s. 5).

24 Preambuła ta brzmiała: „Własność społeczna jest podstawą ustroju Polskiej Rzeczypospolitej Ludowej. Polska Rzeczpospolita Ludowa otacza własność społeczną szczególną troską i opieką oraz zapewnia jej szczególną ochronę. Każdy obywatel Polskiej Rzeczypospolitej Ludowej obowiązany jest strzec własności społecznej i umacniać ją jako niewzruszoną podstawę rozwoju Państwa, źródło bogactwa i siły Ojczyzny. Wszelkie zamachy na własność społeczną winny być surowo karane. W celu wzmożenia ochrony własności społecznej stanowi się, co następuje [...]”.

25 Pojęcie społecznego niebezpieczeństwa było używane przez autorów po wejściu w życie Kodeksu karnego z 1969 r., który termin ten wprowadzał.

26 O. GóRniok: Zagarnięcie..., s. 8.

27 J. KLIMEK: Ochrona..., s. 3. 
za wyjątkowo niebezpieczne społecznie. Zdaniem tego autora zagarnięcie mienia społecznego jest czynem społeczne szkodliwym, ponieważ utrudnia: 1) planowanie i wzmacnianie spójni gospodarczej między miastem a wsią, 2) udzielanie szczególnego poparcia i wszechstronnej pomocy spółdzielniom produkcyjnym oraz 3) rozwój ruchu spółdzielczego w mieście i na wsi ${ }^{28}$. Autor ten wskazywał również, że zamachy na własność państwową wykazują wyższy stopień społecznego niebezpieczeństwa niż te godzące we własność spółdzielczą, a to z tej przyczyny, że własność państwowa jest własnością całego narodu, zaś spółdzielcza wyłącznie własnością poszczególnych grup obywateli ${ }^{29}$. Z tezą tą zdawał się nie zgadzać L. Lernell, który opowiadał się za brakiem przesłanek przemawiających za surowszym karaniem zamachów na własność państwową niż inne rodzaje własności społecznej ${ }^{30}$, jednocześnie wiążąc poziom społecznego niebezpieczeństwa zagarnięć mienia społecznego głównie z rozmiarem ubytku, który powstał we własności społecznej ${ }^{31}$.

Uzasadnieniem ostrzejszej prawnokarnej reakcji za czyny godzące w mienie społeczne był również szereg racji kryminalnopolitycznych. W okresie powojennym zwiększenie ustawowego zagrożenia karą uzasadniano nagminnością tego typu czynów ${ }^{32}$. W okresie późniejszym, gdy zmieniła się struktura przestępczości godzącej w mienie społeczne, tj. najdotkliwsze okazały się nie zagarnięcia drobne, lecz te dokonywane przez zorganizowane grupy, częstotliwość występowania takich czynów przestała mieć znaczenie. Jak pisała O. Górniok, „okazało się, że najpoważniejsze zagrożenie dla własności społecznej stwarzają zamachy dokonywane przez sprawców współdziałających ze sobą w różnych formach i powiązaniach. Nie były one nigdy i nie są nagminne. Na ich wysoki stopień społecznego niebezpieczeństwa składają się przede wszystkim znaczne z reguły straty powodowane w gospodarce uspołecznionej" ${ }^{33}$. L. Lernell odwoływał się również do psychologicznego nastawienia sprawcy do czynu, które jest odmienne w zależności od właściciela mienia będącego przedmiotem zagarnięcia. Pisał on: „gdy sprawca przestępstwa jest przeświadczony, że właścicielem zagarniętego mienia jest państwo, jego postawa psychiczna formuje się pod wpływem szeregu procesów motywacyjnych (a zarazem rozgrzeszających). Jednym $z$ takich procesów jest przeświadczenie, że własność będąca przedmiotem zamachu jest bezosobowa, anonimowa, abstrakcyjna. Na ogół sprawca zamachu na mienie

\footnotetext{
28 W. Gutenkunst: Zagarnięcie..., s. 19.

${ }^{29}$ Ibidem, s. 20.

${ }^{30}$ L. LERNELL: Własność..., s. 145.

${ }^{31}$ Ibidem, s. 342.

32 Ibidem, s. 173.

33 O. GóRnIoK: Zagarnięcie..., s. 85.
} 
(nawet wielkich korporacji) personifikuje pośrednio w wyobraźni właściciela jako ofiarę swojego czynu. Trudno jednak sobie wyobrazić personifikację właściciela, którym jest państwo" 34 . Autor ten obrazowo również przekonywał, że „siódme przykazanie dekalogu »nie kradnij« znajduje w stosunku do mienia społecznego słabszy oddźwięk w psychice ludzi aniżeli w stosunku do mienia prywatnego" 35 .

Wraz z nowelizacją d.k.k. z dnia 23 lutego 1990 r. ${ }^{36}$, wynikającą ze zmiany ustroju politycznego, usunięto $\mathrm{z}$ tego kodeksu niektóre typizacje chroniące własność społeczną oraz zrównano ze sobą zagrożenie karą za czyny zabronione, których przedmiotem czynności wykonawczej było mienie, niezależnie od jego formy. Mimo to pojęcie mienia społecznego pozostało $\mathrm{w}$ zestawie ustawowych znamion tych przepisów aż do wejścia w życie k.k. z 1997 r.

\section{Nowelizacja Kodeksu karnego z dnia 10 lutego 2017 r.}

W tym miejscu konieczne jest przedstawienie zasadniczych punktów nowelizacji Kodeksu karnego z dnia 10 lutego 2017 r., wprowadzającej przepisy prawnokarne dotyczące szczególnych postaci fałszu materialnego i intelektualnego dokumentów, których przedmiotem czynności wykonawczych jest faktura ${ }^{37}$. W dodanym art. 270a $\$ 1$ k.k. odrębnie od art. 270 § 1 k.k. stypizowano pod groźbą kary od 6 miesięcy do 8 lat pozbawienia wolności podrobienie lub przerobienie faktury w zakresie okoliczności faktycznych mogących mieć znaczenie dla określenia wysokości należności publicznoprawnej lub jej zwrotu albo zwrotu innej należności o charakterze podatkowym w celu użycia za autentyczną lub używanie takiej faktury jako autentycznej. Przepis art. 270a §2 k.k. przewiduje

34 L. LERNELL: Rozważania o przestępstwie i karze na tle zagadnień wspótczesności. Warszawa 1975, s. 285-286.

${ }^{35}$ L. LeRnell: Własność..., s. 11. Na zależność tę wskazywał już C. Beccaria, oceniając, że przestępstwo kontrabandy, z racji, że nie dotyka ludzi bezpośrednio, nie wzburza w nich poczucia sprzeciwu (por. C. BeCCARIA: O przestępstwach $i$ karach. Przeł. E.S. RaPPAPORT. Warszawa 1959, s. 181).

${ }^{36}$ Ustawa z dnia 23 lutego 1990 r. o zmianie Kodeksu karnego i niektórych innych ustaw, Dz.U. nr 14, poz. 84.

${ }^{37}$ Pojęcie faktury zostało zdefiniowane w dodanym przepisie art. 115 ust. 14a k.k. przez odniesienie do terminologii przyjętej na gruncie Ustawy z dnia 11 marca 2004 r. o podatku od towarów i usług, t.j. Dz.U. 2018, poz. 2174 ze zm. W jej rozumieniu przez fakturę należy rozumieć dokument w formie papierowej lub w formie elektronicznej zawierający dane wymagane ustawą i przepisami wydanymi na jej podstawie (art. 2 pkt 31 ustawy o VAT). Takimi elementami są między innymi data wystawienia, oznaczenie podatnika i nabywcy towaru, nazwa (rodzaj) towaru lub usługi czy cena jednostkowa towaru (art. 106e ustawy o VAT). 
z kolei typ kwalifikowany przez okoliczność w postaci dopuszczenia się powyższego czynu wobec faktury lub faktur, zawierających kwotę należności ogółem, której wartość lub łączna wartość jest większa niż pięciokrotność kwoty określającej mienie wielkiej wartości ${ }^{38}$, albo uczynienia sobie z popełnienia przestępstwa stałego źródła dochodu. Zagrożenie karą w tym wypadku przesądza o uznaniu takiego czynu za zbrodnię, gdyż jego sprawca podlega karze pozbawienia wolności na czas nie krótszy od lat 3.

$\mathrm{Z}$ kolei odmiana fałszu intelektualnego dokumentu została uregulowana $\mathrm{w}$ art. $271 \mathrm{a} \S 1$ k.k., zgodnie z którym podlega karze pozbawienia wolności na czas od 6 miesięcy do lat 8 , kto wystawia fakturę lub faktury, zawierające kwotę należności ogółem, której wartość lub łączna wartość jest znaczna ${ }^{39}$, poświadczając nieprawdę co do okoliczności faktycznych mogących mieć znaczenie dla określenia wysokości należności publicznoprawnej lub jej zwrotu albo zwrotu innej należności o charakterze podatkowym lub takiej faktury lub faktur używa. Analogicznie do powyższego ustawodawca uregulował typ zmodyfikowany, gdzie okolicznością kwalifikująca jest wystawienie faktury lub faktur, zawierających kwotę należności ogółem, której wartość lub łączna wartość jest większa niż pięciokrotność kwoty określającej mienie wielkiej wartości, bądź uczynienie sobie z przestępstwa stałego źródła dochodu. Zarówno w przypadku fałszu materialnego, jak i intelektualnego faktury ustawodawca przewidział możliwość orzeczenia łagodniejszej kary (tak w odniesieniu do typu podstawowego, jak i kwalifikowanego tych czynów zabronionych) w przypadku mniejszej wagi (art. 270a § 3 k.k. i 271a § 3 k.k.). Z kolei art. 277a $\$ 1$ k.k. przewiduje karę pozbawienia wolności na czas nie krótszy od lat 5 lub karę 25 lat pozbawienia wolności za popełnienie czynu polegającego na wyczerpaniu znamion art. $270 \mathrm{a} \S 1$ k.k. albo $271 \mathrm{a} \S 1 \mathrm{k} . \mathrm{k}$. wobec faktury lub faktur, zawierających kwotę należności ogółem, której wartość lub łączna wartość jest większa niż dziesięciokrotność kwoty określającej mienie wielkiej wartości.

Nie jest jednak przedmiotem niniejszego artykułu dogłębna analiza przyjętych rozwiązań, lecz ocena, czy przyjęta nowelizacja stanowi powrót do szczególnej prawnokarnej ochrony mienia społecznego. W tym celu zasadne jest zbadanie racji przemawiających za przyjęciem opisywanej nowelizacji i przyrównanie ich do przedstawionych powyżej przesłanek tłumaczących zaostrzenie represji karnej grożącej podówczas za ataki na

${ }^{38}$ Kwotą określającą mienie wielkiej wartości jest 1 mln zł (art. 115 § 6 k.k.), zatem dla przyjęcia tego typu kwalifikowanego wartość faktury lub faktur musi obejmować przeszło 5 mln zł.

39 Pojęcie znacznej wartości lub łącznej wartości należy rozumieć odpowiednio do mienia znacznej wartości, o którym mowa w art. $115 \S 5 \mathrm{k} . \mathrm{k}$. Zatem przyjąć należy, że wartość wyrażona na fakturach, by zostać uznaną za znaczną, musi przekroczyć 200 tys. zł. 
mienie społeczne. Analizy tej można dokonać poprzez lekturę uzasadnienia złożonego przez projektodawcę (Ministerstwo Sprawiedliwości) wraz z projektem ustawy ${ }^{40}$. Prowadzi ona do wniosku, że zasadniczym powodem przemawiającym za koniecznością przyjęcia opisywanej nowelizacji było działanie w celu ochrony interesów Skarbu Państwa. Na powyższe wielokrotnie wskazuje projektodawca $\mathrm{w}$ treści uzasadnienia projektu ${ }^{41}$. Z pewnością zaś mienie Skarbu Państwa mieści się w nieistniejącej już kategorii normatywnej mienia społecznego.

Co warte odnotowania, projektodawca odnosi interes budżetowy Skarbu Państwa do podstawowych dóbr państwa. Przykładowo czyny objęte nowelizacją, w opinii projektodawcy, należy sytuować w jednym rzędzie z najpoważniejszymi przestępstwami przeciwko Rzeczypospolitej Polskiej $^{42}$, zaś dobrem chronionym penalizowanych czynów „przestaje być sam budżet państwa, a staje się wręcz bezpieczeństwo wewnętrzne i fundamenty funkcjonowania państwa" ${ }^{43}$. Za przyjętą nowelizacją w opinii projektodawcy przemawiała również skala zjawiska ${ }^{44}$, przy czym nie tyle chodzi tu o jego nagminność, co o szkody powodowane w budżecie państwa. Kolejną z racji uzasadniających wzmożenie sankcji grożących za czyny objęte nowelizacją jest okoliczność, że działalność ta narusza interesy „społeczeństwa jako całości i każdego z jego członków z osobna”, gdyż państwo jest w mniejszym w stopniu w stanie podołać potrzebom redystrybucyjnym ${ }^{45}$. Projektodawca zdawał się również uzasadniać konieczność przyjęcia nowelizacji znaczną społeczną szkodliwością tych czynów, wiążąc jej poziom z kwotą ujawnioną na fakturze, nie zaś rzeczywistą szkodą poniesioną przez Skarb Państwa.

Powyższe przemawia za tezą, że racje stojące za przyjęciem czynów zabronionych składających się na przedmiotową nowelizację pozostają $\mathrm{w}$ analogii z przedstawionymi powyżej wypowiedziami dającymi uza-

40 Uzasadnienie rządowego projektu ustawy o zmianie ustawy - Kodeks karny oraz niektórych innych ustaw (Druk Sejmowy nr 888, Sejm VIII kadencji). Źródło: http://orka. sejm.gov.pl/Druki8ka.nsf/0/EA8BC112272EA7CEC125804200323EDD/\%24File/888uzas.docx [dostęp: 10.10.2019].

${ }^{41}$ Por. m.in. Uzasadnienie..., s. 1, 5-7 oraz 11.

42 Ibidem, s. 6.

${ }^{43}$ Ibidem, s. 7; niezależnie od powyższego projektodawca podnosi, że cel w postaci zwalczania przestępczości zorganizowanej opisywanego rodzaju można osiągnąć przez penalizację przestępstw przeciwko dokumentom (ibidem, s. 4). Na podstawie uzasadnienia nie sposób zatem określić, czy przedmiotem ochrony w przypadku czynów zabronionych wprowadzonych nowelizacją jest własność Skarbu Państwa, bezpieczeństwo wewnętrzne państwa czy też wiarygodność dokumentów. Na wszystkie te dobra wskazuje bowiem projektodawca. Wydaje się, że rozstrzygając to zagadnienie, nie można poprzestać na ocenie umiejscowienia typizacji objętych nowelizacją w Kodeksie karnym.

${ }^{44}$ Ibidem, s. 5, 6.

45 Ibidem, s. 6. 
sadnienie dla szczególnej prawnokarnej ochrony mienia społecznego w okresie Polski Ludowej. Poczynić jednak należy oczywiste zastrzeżenie, że współcześnie nie jest stosowana retoryka wypływająca z socjalistycznej ideologii oraz komunistycznej wizji państwa. Warte zwrócenia uwagi jest, że w obu porównywanych okresach racją uzasadniającą wprowadzenie przepisów prawa karnego był cel w postaci lepszego zaspokajania potrzeb członków społeczeństwa. W 1953 r. L. Lernell cel ten określił jako „ochronę interesów człowieka pracy”, zaś uzasadnienie nowelizacji odniosło go do ochrony interesów każdego z członków społeczeństwa z osobna. Uzasadnienie przyjętej nowelizacji powieliło również argumentację odnoszącą się do zagrożenia kryminalizowanymi czynami interesów państwa oraz znaczną społeczną szkodliwością (niebezpieczeństwem) tych czynów. W świetle uzasadnienia projektu nowelizacji niemal zupełnie aktualne pozostają przytoczone powyżej słowa O. Górniok z 1976 r., która łączyła społeczne niebezpieczeństwo czynów godzących w mienie społeczne nie $\mathrm{z}$ ich nagminnością, lecz skalą oraz sposobem działania sprawców, którzy współdziałali ze sobą w różnych formach i powiązaniach.

W analizowanym zakresie nie tylko uzasadnienie nowelizacji przypomina argumentację autorów z okresu Polskiej Rzeczypospolitej Ludowej, ale również środki, które prawodawca postanowił zastosować. Sens wyróżniania typów, wśród znamion których znajdowało się mienie społeczne, wynikał z zamiaru opatrzenia danych czynów surowszym zagrożeniem karą niż zachowań godzących w inne rodzaje mienia ${ }^{46}$. Ten sam środek zastosował współczesny ustawodawca, przewidując za czyny zabronione wprowadzone opisywaną nowelizacją ustawowe zagrożenie karą znacznie przewyższające te za ataki na własność dokonywane w inny sposób, i to pomimo tego, że działalność polegająca na fałszerstwie faktur VAT pozostaje daleko na przedpolu naruszenia dobra prawnego $\mathrm{w}$ postaci własności państwowej. Odwraca to zatem zwykłą relację między zagrożeniami karą przewidzianymi za narażenie i naruszenie dobra, w której to naruszenie, jako bardziej społecznie szkodliwe, spotyka się z surowszą penalizacją. Co jednak warte odnotowania, w odróżnieniu od analizowanych historycznych norm wprowadzone do Kodeksu karnego regulacje w określonych wypadkach przewidują możliwość skorzystania przez

${ }^{46}$ Odnotować jednak należy, że w ramach kampanii walki z oszustwami podatkowymi ustawodawca nie ograniczył się wyłącznie do sięgania po narzędzia prawnokarne. Przykładowo Ustawą z dnia 1 grudnia 2016 r. o zmianie ustawy o podatku od towarów i usług oraz niektórych innych ustaw, Dz.U. poz. 2024, poza zaostrzeniem sankcji grożących za szereg przestępstw skarbowych, w tym odnoszących się do tu prowadzonych rozważań, znacznie znowelizowano samą ustawę o podatku od towarów i usług poprzez wprowadzenie regulacji mających na celu przeciwdziałaniu opisywanej przestępczości. 
sprawcę z dobrodziejstw czynnego żalu w postaci nadzwyczajnego złagodzenia kary lub odstąpienia od wymierzenia kary (art. 277c k.k.).

W 2000 r. O. Górniok podnosiła, że kwalifikowanie jako przestępstwa skarbowe występków „wówczas, gdy ich sprawcy pozorują zobowiązania podatkowe po to, ażeby wykorzystać procedurę podatku VAT dla wyprowadzenia wartości majątkowych z władztwa Skarbu Państwa, uprzywilejowuje ich w stosunku do tych, którzy doprowadzają do tego samego skutku za pomocą innych oszukańczych manipulacji", a to ze względu na łagodniejsze kary, którymi dysponuje prawo karne skarbowe ${ }^{47}$. Odnosząc te słowa do obecnie obowiązującego stanu prawnego, można skonstatować, że wraz z opisywaną nowelizacją nie tylko się one zdezaktualizowały, lecz w gruncie rzeczy można postawić tezę przeciwną. Otóż obecnie to sprawcy wyprowadzający wartości majątkowe z władztwa Skarbu Państwa, lecz w inny sposób niż przez wykorzystanie mechanizmów podatku VAT, znajdują się w pozycji uprzywilejowanej, gdyż ich działanie niezależnie od kwoty będącej przedmiotem zamachu - z pewnością nie zostanie zakwalifikowane jako zbrodnia.

\section{Podsumowanie}

Podsumowując, należy uznać, że przy przyjęciu dawnej terminologii nowelizacja Kodeksu karnego z dnia 10 lutego 2017 r. może zostać uznana za przejaw prawnokarnej ochrony mienia społecznego. Jej uzasadnieniem jest bezspornie ochrona interesów majątkowych Skarbu Państwa, dla którego - w ocenie prawodawcy - oszustwa przy pomocy faktur VAT są na tyle groźne, że wymagają szczególnych rozwiązań prawnokarnych karalności na przedpolu naruszenia dobra prawnego, uniezależnionego od poniesionego przez Skarb Państwa uszczerbku, oraz zagrożenia karą nieproporcjonalną do tej grożącej za inne zamachy na własność czy wiarygodność dokumentów.

Przyjętemu wnioskowi nie stoi na przeszkodzie kryminalizacja przedmiotowych zachowań $\mathrm{w}$ formie kwalifikowanych przestępstw przeciwko wiarygodności dokumentów. Nie można bowiem przy określeniu przedmiotu zamachu poprzestać na analizie umiejscowienia typizacji w strukturze kodeksu. Bez wątpienia, na co wskazują komentatorzy, czyny te są skierowane przeciwko wiarygodności dokumentu w postaci faktury $\mathrm{VAT}^{48}$. Obok wskazanego dobra przedmiotem ochrony jest również in-

${ }^{47}$ O. GóRnIOK: Jeszcze o nadużyciach procedury podatku VAT. Prok. i Pr. 2000, nr 6, s. 22.

${ }^{48}$ Tak m.in. A. Herzog. W: Kodeks karny. Komentarz. Red. R.A. StefańsKI. Warszawa 2018, s. 1685 oraz 1693; M. GaŁĄzKA. W: Kodeks karny. Komentarz. Red. A. GrzeŚKowiaK, 
teres majątkowy państwa ${ }^{49}$. Sam projektodawca przyznał w uzasadnieniu projektu, że „koncentrując się na penalizacji przestępstw przeciwko dokumentom (wiarygodności faktur), można osiągnąć skutek w postaci unicestwienia najważniejszego instrumentu służącego wyłudzeniom podatku VAT" 50 . Taki, a nie inny kształt wprowadzonych opisywaną nowelizacją typizacji wynika wyłącznie z podejścia instrumentalnego, tj. przekonania, że doprowadzi to do zapobiegnięcia szkodom w mieniu Skarbu Państwa, podobnie jak dla sprawców inkryminowanych zdarzeń dokonanie fałszerstwa faktury również jest wyłącznie środkiem, nie zaś celem samym w sobie. Przedmiotem głosów polemicznych powinno być jednak zagadnienie, czy w tym wypadku prawodawca nie wyszedł zbytnio na przedpole naruszenia dobra, gdy niebezpieczeństwo dla dobra prawnego w postaci mienia Skarbu Państwa nie jest jeszcze nawet bezpośrednie. Wydaje się, że rzeczywiście tak daleko idące wyróżnienie prawnokarnej ochrony interesów państwowych ${ }^{51}$, wbrew opinii projektodawców, godzi - przynajmniej w zakresie typów przewidujących najsurowsze sankcje - w konstytucyjną zasadę proporcjonalności stanowiącą ramy dopuszczalnej prawnokarnej represji ${ }^{52}$.

\section{Bibliografia}

\section{Literatura}

BeCCARIa C: O przestępstwach i karach. Przeł. E.S. Rappaport. Warszawa 1959.

GatązKa M. W: Kodeks karny. Komentarz. Red. A. GrześKowiaK, K. WiaK. Warszawa 2019.

K. WiaK. Warszawa 2019, s. 1339 oraz 1346; A. LaCH. W: Kodeks karny. Komentarz. Red. V. Konarska-Wrzosek. Warszawa 2018, s. 1216 oraz 1221; T. Sroka. W: Kodeks karny. Część szczególna. T. II. Red. W. WróBel, A. Zoll. Warszawa 2017, s. 719 oraz 756.

49 Słusznie podnosi M. Żelichowski, że indywidualny przedmiot ochrony w przypadku typizacji z art. 270a i 271a k.k., tj. interesy majątkowe Skarbu Państwa, ma charakter nadrzędny nad przedmiotem ochrony rodzajowym w postaci wiarygodności faktur. Por. M. Żelichowski. W: Kodeks karny. Część szczególna. T. II. Red. M. KrólikowsKi, R. ZAWŁOCKI. Warszawa 2017, s. 526 oraz 543.

${ }^{50}$ Druk Sejmowy nr $888 \ldots$... s. 4.

${ }^{51}$ Ibidem, s. 6. Projektodawca spełnienie zasady proporcjonalności wyprowadzał z twierdzenia o analogii typizacji objętych nowelizacją z najpoważniejszymi przestępstwami przeciwko Rzeczypospolitej Polskiej.

52 Por. M. Mozgawa. W: Kodeks karny. Komentarz. Red. M. Mozgawa. Warszawa 2017, s. 839 oraz T. SRoкA. W: Kodeks..., s. 732, który wskazuje, że „sąd, chcąc uniknąć stosowania względem jednostek nieproporcjonalnej w perspektywie Konstytucji RP reakcji karnej, powinien wymierzać karę za przestępstwo $\mathrm{z}$ art. $270 \mathrm{a} \$ 2 \mathrm{w}$ dolnych granicach ustawowego zagrożenia, ewentualnie - w razie spełnienia przesłanek - kwalifikować zachowanie sprawcy jako wypadek mniejszej wagi z art. 270a §3”. 
GnieweK E.: Rozdział V. Treść i wykonywanie prawa własności. W: System prawa prywatnego. Prawo rzeczowe. T. 3. Red. E. GNIEwEK. Warszawa 2013.

GóRnioK O.: Jeszcze o nadużyciach procedury podatku VAT. Prok. i Pr. 2000, nr 6.

GóRnioK O.: Zagarnięcie mienia społecznego. Warszawa 1976.

GuTENKUnst W.: Niektóre problemy kodyfikacji przestępstw przeciwko własności. PiP 1957, nr 10.

GuTENKUNST W.: Zagarnięcie mienia społecznego. Warszawa 1956.

Herzog A. W: Kodeks karny. Komentarz. Red. R.A. StefańsKi. Warszawa 2018.

KLIMEK J.: Ochrona mienia społecznego w prawie karnym. Warszawa 1982.

KonArsKa-WrzoseK V.: Przestępstwa fakturowe - ich waga, kwalifikacja prawna $i$ miejsce $w$ systemie polskiego prawa karnego. IN 2017, nr 2.

Lach A. W: Kodeks karny. Komentarz. Red. V. KonArSKA-WrzoseK. Warszawa 2018.

LERNELL L.: Nasze ustawodawstwo karne na straży własności społecznej i interesów mas pracujacych. NP 1953, nr 3.

LERNELL L.: Ochrona mienia publicznego i osobistego $w$ radzieckim prawie karnym. PiP 1947, nr 11.

LERNELL L.: Ochrona własności społecznej w prawie karnym. T. I: Nauka marksizmu-leninizmu o ochronie własności socjalistycznej. Warszawa 1954.

LERNELL L.: Rozważania o przestępstwie i karze na tle zagadnień współczesności. Warszawa 1975.

LERNELL L.: Własność społeczna jako przedmiot ochrony prawa karnego: o przedmiocie przestępstwa zagarnięcia mienia społecznego. Warszawa 1959.

Mozgawa M. W: Kodeks karny. Komentarz. Red. IDEM. Warszawa 2017.

RADZIKOWsKI K.: Nowelizacja kodeksu karnego i kodeksu karnego skarbowego w zakresie tzw. przestępstw fakturowych. „Przegląd Podatkowy” 2017, nr 3.

Sroka T. W: Kodeks karny. Część szczególna. T. II. Red. W. Wróbel, A. Zoll. Warszawa 2017.

Stelmachowski A., Zaradkiewicz K.: Rozdziat IV. Modele własności i ich uwarunkowania społeczno-ustrojowe. W: System prawa prywatnego. Prawo rzeczowe. T. 3. Red. E. GNIEWEK. Warszawa 2013.

ZAwŁocKI R.: Rozdziat I. Przestępstwa przeciwko mieniu. Zagadnienia ogólne. W: System prawa karnego. Przestępstwa przeciwko mieniu i gospodarcze. T. 9. Red. IDEM. Warszawa 2015.

Żelichowski M. W: Kodeks karny. Część szczególna. T. II. Red. M. KrólikowsKi, R. ZAwŁoCKI. Warszawa 2017.

\section{Źródła inne}

Uzasadnienie rządowego projektu ustawy o zmianie ustawy - Kodeks karny oraz niektórych innych ustaw (Druk Sejmowy nr 888, Sejm VIII kadencji). 